\title{
Urban Slums: Environmental Sustainability at A Cross Road
}

\author{
Ibimilua Foyeke Omoboye ${ }^{1}$, Ibimilua Adewale Festus ${ }^{2 *}$ \\ ${ }^{1}$ Department of Geography, School of Arts and Social Sciences, College of Education, Ikere-Ekiti, Nigeria \\ ${ }^{2}$ Department of Geography and Planning Science, Faculty of the Social Sciences, Ekiti State University, Ado-Ekiti, Nigeria
}

DOI: $\underline{10.36348 / \text { sjhss.2020.v05i03.008 }}$ | Received: 17.03 .2020 |Accepted: 24.03 .2020 | Published: 30.03 .2020

*Corresponding author: Ibimilua Adewale Festus

\section{Abstract}

This research examines a contemporary but disturbing issue in environmental management using Nigeria as a case study. The study probes the major causes, consequences and solutions to urban slums. Using secondary sources of data, themes were identified in relation to issues bothering on urban slums. The paper identifies rural-urban migration, population, explosion, poverty, unemployment, shortage of housing, neglect, poor physical development, poor transportation network, as well as poor waste management as the major causes of urban slums. Similarly, the review indicates that shortage of housing, unemployment, inadequate social infrastructure, waste management, environmental degradation, crimes, insecurity, land use conflicts, health hazards, population, and other ecological hazards as the negative consequences of slums. Additionally, this paper addresses the issue of environmental sustainability by emphasizing that slums are cogs in the wheels of sustainable development. To this end, the study recommends urban redevelopment, sum upgrading, poverty alleviation, provision of employment, provision of social and infrastructural amenities, sustainable waste management, as well as resettlement schemes as measures to sustainable urban environment.

Keywords: Environment, Management, Poverty, Slum, Sustainability, Urbanization.

Copyright @ 2020: This is an open-access article distributed under the terms of the Creative Commons Attribution license which permits unrestricted use, distribution, and reproduction in any medium for non-commercial use (NonCommercial, or CC-BY-NC) provided the original author and source are credited.

\section{INTRODUCTION}

The problems of slum have received a global attention from many fields of academic endeavor geography, planning, sociology, political science, psychology, engineering, medicine, architecture, demography, environmental management, and criminology. This is due mainly to its detrimental consequences on man and his environment. It is a great challenge to environmental sustainability. The term slum has been defined and described variously by many scholars [1-6]. For instance, [3] defined it as a group of buildings, or an area characterized by overcrowding, deterioration, unsanitary conditions, or absence of facilities or amenities. Also, UN-HABITAT quoted in [7] estimated that more than 800 million people live in urban slums in the developing world, often under conditions so squalid that they defy description.

Moreover, [5] noted that cities as the most complex human creation, are at great risk both from a wide range of hazards and from their own multiple vulnerabilities. The problem of slum is caused mainly by the process of urbanization. Consequently, slum formation is a repercussion of urbanization. Rapid urbanization comes with myraids of problems [8]. In fact, United Nations quoted in [9] noted that over one billion of the world's population live in urban slums without access to safe water, acceptable sanitation and secure, tenured housing of acceptable standard.

A large percentage of the population across the world are living in slum environments and dingy structures. It is estimated that more than one billion people in the world live in slums. By 2030, it is likely that five billion people will be living in cities. Four billion of these will be living in cities of the developing world [6]. The urban slums are characterized by dilapidated structures and abandoned buildings. The defective structures degrade the environment in several ways. They are usually overgrown by bushes, and they decline environmental aesthetics. Also, environmental safety is threatened in the urban slums by the presence of abandoned buildings. These ghettos are used by lunatics, juvenile delinquents, hooligans, drug addicts and armed robbers as their hideouts.

Urbanization is caused by the push from the country side and pull to the city. Hence, the migration of people to the city as well as natural increase are responsible for urbanization. There are so many advantages of urbanization. Among them are material 
and economic progress, cultural diversity, development of new skills and technologies, as well as expansion of markets just to mention a few. Nevertheless, the process of urbanization constitutes a series of problems within the cities. Among them are the growth of slums and squatter settlements, deteriorating infrastructure, environmental pollution, as well as traffic congestion.

Slum dwelling is a common phenomenon all over the world. It is rampant in many cities of developing countries. On this note [10] noted that slum areas are inhabited by the poor. Low income people are attached to the inner city slums because of the low rentage value of accommodation. Consequently, the slum areas are characterized by structural and sanitary disorder. The slums are also typified by the menace of solid waste, conflicts, fears, fire outbreak, and environmental pollution.

The core areas of urban centres are inhabited by tenants and/or low income earners. In these areas, deterioration and decay set in as a result of poor maintenance. The inner cities are designated by a combination of feebly rooted social, economic and physical conditions. The low income earners live in substandard, dilapidated, and squatter settlements. These are associated with environmental pollution, waste disposal problem, traffic congestion, shortage of water, encroachment into agricultural land, as well as building decay and abandonment. Other features of squatter settlements are lack of access to basic services like water, sanitation, and health services.

The major challenges in the urban slums are overpopulation, high rate of unemployment, inadequate housing, poor maintenance of existing structures, environmental decay, blocked drainage systems, insufficient parking facilities, traffic congestion, and high rate of accidents. Others are inadequate amenities, pollution of all types, waste management problem, shortage of water, health hazard, as well as high rate of crime [11]. Other predicaments of urbanization include climate change, ozone depletion, urban heat, and other environmental issues.

\section{URBANIZATION}

Urbanization is a process by which a settlement is transformed from a rural to an urban way of life (technology, and systems of production commerce and administration) [12]. Globally, the causes and consequences of urbanization have caught the attention of many researchers $[1,3,4,5,13,14,15]$. The factors that aid urban development include commercial activities, availability of industries, favourable climatic factor, existence of social amenities and infrastructure, improved medical and social facilities, as well as good transportation network.

There are so many reasons for urbanization. For instance [16], identified the reasons for urbanization as natural population growth, market potentials, increased education, industrialization, improvement in transport services, increased services activities, as well as social and cultural attractions. Urbanization is a necessary step in the inevitable trend of modern human and social development that promotes industrial structural adjustment [17]. The major prospects of urbanization include increase in labour force, large source of market, propensity for increment in investment and productivity, diversity talents and skills, as well as attraction of foreign aids. Other potentials are promotion of cultural integrity, reduction of pressure on rural lands, as well as propensity for 'trickling down effect' of development to rural areas.

The problems of urbanization include the economic, social, physical and political issues. Others are waste disposal, building decay, environmental pollution, food and water scarcity, traffic congestion, as well as encroachment to agricultural lands. Also, the solutions to urban problems include implementation of urban housing programmes, good urban governance and administration, rural development, urban development control, execution of urban master plans, as well as creation of new towns. Others are control of traffic, establishment of good communications, control of rural-urban migration, as well as establishment of satellite towns [see 18].

Experts in rural planning have posited that notable problems or urbanization are pressure on infrastructural amenities, congestion and overcrowding, increase in crime values, environmental pollution, as well as health challenges. Other plights are inadequate housing, unemployment, duress on available resources, traffic congestion, stress on social amenities, as well as reduction in standard of living. Major solutions to the problems of urbanization are control of urban growth, improvement in urban conditions, regular supply of social and infrastructural amenities, poverty alleviation, creation of new towns, as well as development and planning of rural areas.

\section{URBAN SLUM AND ITS CAUSES}

Urban centres across the world are characterized by several problems $[1,2,4,5,16,18$, 19]. Among them are slum formation, environmental degradation, traffic congestion, shortage of water, as well as environmental pollution. Other challenges are threat to agricultural land, poor housing condition, poverty, waste disposal problem, insufficient jobs and inadequate social facilities. Urban slums are harmful to man and the environment. In slums, there are poor housing conditions (in quality and quantity), low rent, poor maintenance, as well as poor sanitary condition.

The reasons for urbanization include employment, job transfer, higher education, marriage, political appointment, commerce, tourism, as well as enjoyment of social and infrastructural facilities. All these culminate to slum formation and overcrowding most especially at the city centre. Urban slums are 
caused by natural increase in population as well as immigration of people to urban centres. Migration into urban centres is caused by search for employment opportunities, neglect of the rural areas, as well as quest for improved recreation and tourism facilities.

The agglomeration of people in the urban centres is the major cause of slum. The influx of people to the urban centres is characterized by the growth of trade, industry, housing, employment and commerce. Eventually, the over-concentration of people, most especially at the core areas is responsible for urban slum. Other causes of slum formation are poverty, illiteracy, unemployment, lack of maintenance of the physical environment, as well as poor enforcement of environmental laws and regulations. All these factors are responsible for poor housing, overcrowding, broken families, and deteriorating environmental conditions. Moreover, urban slums result from haphazard planning and anti-planning. Also, it emanates from poor management and non-implementation of existing environmental planning laws.

\section{CONSEQUENCIES OF URBANIZATION AND URBAN SLUMS}

The environmental implications of urban slums are multi-dimensional. Researches have confirmed that there are positive and negative consequences of urban slums and slum dwelling [2024]. For example [20] identified the benefits of urbanization as job opportunities, better quality of life, good transportation facilities, improved water supply and services, diffusion of ideas, as well as the overall economic growth of the nation. Other positive aspects are availability of more specialized and efficient skills, as well as the availability of unskilled labour force.

It has been established by [25] that rapid urbanization, concentration of urban population in large cities, the sprawl of cities into wider geographical areas and rapid growth of mega cities are having adverse consequences on man and his environment. The negative consequences of urban slums include insufficient housing, deterioration of municipal services, high rate of unemployment, poor sanitation, high rate of crime, over- crowding, unsatisfactory health services, as well as pressure on the available social and infrastructural amenities. It has great effects on man and his environment. The aftermaths include traffic congestion, unplanned development, environmental pollution, inadequate housing, health challenge, insufficient amenities, menace of waste, as well as crime.

The urban environment is a centre of activity for all sorts of antisocial behaviours such as prostitution rape, robbery, drunkenness, and so on [20]. For short, the urban slum is the harbor for unsocialised and mentally deranged people. Researches have confirmed that the city centres with low income earners, deteriorated housing quality, disorganized families, least developed neighbourhood institutions and high rate of truancy are the major sources of insurgencies, conflicts and criminalities [5, 6, 13, 22, 26].

From the foregoing, it is crystal clear that defective structures usually constitute a betide for hoodlums and criminals, thereby threatening environmental safety and security. Crime tends to occur with greater frequency in poorer parts of richer countries and in poorer neighbourhoods of all cities, but it can occur anywhere [26]. Criminals are concentrated in urban slums because of the favourable environmental conditions for criminalities. On this note, [26] argued that crime is often concentrated in places that cluster criminal opportunities.

Crime spreads across varied urban settings and becomes a part of the daily rhythm of urban living. Crime concentrates in 'hot sports' times and spaces in which large numbers of offenders find and exploit many criminals' opportunity [26]. Urban slums are perceived as generator and attractors of crime, violence and insecurity. They are also noted for anti-social and deviant behaviours like violence, insecurity, prostitution, youthful exuberance, juvenile delinquencies and other criminal acts.

Slum dwelling leads to family breakdown, personal disorganization, diseases and poverty [27]. Other effects of slum dwelling are violence and political radicalism. In order words, the slum is a generator of social deviant behaviours like hooliganism, prostitution, bullying, arson, vandalism, and other antisocial values. It is also responsible for many contagious diseases like cholera, dysentery, typhoid and tuberculosis. Thus, slum dwelling is hazardous to human health and wellbeing.

Slums suffer from serious environmental disadvantages and lack basic facilities. Residents have to cope with clogged drains, stagnant ponds, poor water supply and inadequate waste disposal and sanitation [28]. How and where the built environment is constructed and developed can directly affect outdoor and indoor air quality in urban areas and can impact unspoiled areas and disturb animal habitats by replacing natural cover with impervious concrete or asphalt [29].

\section{ENVIRONMENTAL SUSTAINABILITY}

Sustainable development is one of the major goals of urban growth. It is the practice of development which integrates the needs of people, the economy and the ecosystem in decision making. Moreover [30], perceived sustainable development as that which respects the life quality of future generations and that, which is accomplished through support for viability of earth's resources and ecosystems.

Sustainable development is that which aims at improving the living conditions of the people for a long period of time without jeopardizing the interest of the 
future generations. It is a steady, uninterrupted, undisturbed, and futuristic kind of development. It is measured in terms of time, influence and impact (effect) [31]. Within this context, urban slum and the associated problems are bottlenecks in the achievement of sustainable development.

Environmental sustainability requires the use of environmental resources in such a way that the interest of the future generation is not jeopardized. Sustainable development offers a vision of a future world, which meets the need of all without undermining the integrity of the environment [32]. For development to be sustainable in cities, there should be adequate space standard and improvement in the condition of buildings and the overall quality of the environment. Other measures are adequate supply of social and infrastructural amenities, birth control, slum clearance, and general urban renewal.

The factors that are hindering the achievement of environmental sustainability in urban slums and ghettos include inadequate financial resources for urban development, poor maintenance, inadequate human resources for urban planning, inadequate plan for the future of the urban centres, political instability, as well as lack of continuity in public development projects. However, the consequences of not sustaining urban development include abandonment of projects and properties, increased level of poverty, decline in standard of living, as well as environmental degradation. Other consequences include urban decay and abandonment.

A major way of achieving sustainable development is through urban development and creation of smart cities [33]. Measures of attaining environmental sustainability in urban centres include environmental education, human resources management within the urban frame, slum clearance, as well as political stability and continuity in urban development projects. Sustainable cities can also be achieved by environmental monitoring, mitigation of climate change, sustainable use of energy, poverty alleviation, urban and regional planning, population control, as well as environmental management and planning.

\section{COMBATING URBAN SLUMS}

Remedial measures to the problem of slum include proper management of cities, effective administration of urban development, preparation and implementation of suitable and functional land use plans, as well as implementation of environmental planning laws. Other courses of action are urban redevelopment, completion or renovation of abandoned and/or uncompleted buildings, slum clearance and creation of new towns. Also, in order to enhance the quality of the urban core areas, there should be the rationalization of land use patterns like zoning, building height density, and transport segregation. Above all, there is the necessity for rural development so as to reduce rural-urban migration.

For sustainable livelihood to be achieved in urban areas, there should be changes in public behaviours towards environmental sanitation. This should be accompanied by enactment and enforcement of environmental laws. Other solutions to the menace of slum include provision of housing, slum clearance, poverty alleviation, crime reduction, effective waste management, as well as environmental sanitation. Additional remedial measures are creation of employment, maintenance of existing facilities, pollution abatement, as well as good urban governance. The development of urban slums should be discouraged so as to minimize environmental degradation in urban areas.

The growing concern for urban problems and the quality of urban environment has necessitated the involvement of many stakeholders. Thus in order to ameliorate the menace of slum in our cities, individual's professional bodies, governments, non-governmental organizations, as well as community based organizations should work in collaboration with international organizations.

\section{SUMMARY AND CONCLUSION}

The problem of slum is a topical and contemporary issue across the globe. The menace is disturbing many stakeholders like urban planners, geographers, sociologists, municipal engineers, architects, surveyors and policy makers because of the complexities in the causes, consequences, as well as difficulties in combating the emanating challenges. The factors that favour urban development and slum formation include unfavourable conditions in the rural areas that force the rural dwellers to urban centres, migration of different types (including urban-urban), economic factor, as well as political reason.

Urban centres perform functions like administrative, recreational, industrial, commercial, and religious. All these activities attract people to urban centres and most migrants settle in the urban core areas, thereby increasing the population naturally and anthropogenically. The increment in the population is responsible for urbanization and invariably slum formation. Urbanization has social, economic cultural, administrative and political advantages. On the other hand, the growth of slum is characterized by spread of diseases, shortage of social facilities, unemployment, traffic congestion, poor housing, food scarcity, and pollution of all types.

Findings from this study reveals that the negative implications of slum formation are environmental pollution, high rate of under employment and unemployment, as well as inadequate housing. Other consequences are high cost of living, traffic congestion, pressure on social and infrastructural 
amenities, reduction in standard of living, as well as increase in crime rate. This research revealed further that urban slums are breeding grounds for anti-social and deviant behaviours. These are the major constraints to environmental sustainability.

For the attainment of environmental sustainability, therefore, this study recommends increment of the housing stock in urban centres, upgrading and improvement of existing housing stock, urban and regional planning, as well as the implementation of building regulations and bye laws. Above all, this study recommends the collaborative efforts of all stakeholders in the achievement of sustainable cities. Achieving sustainability in the cities also requires the attainment of environmental, social, political, economic and territorial security. These are the concomitants of sustainable development.

\section{REFERENCES}

1. Blair, T. L. (1974). The international urban crisis. New York, Hill and Wang.

2. Clinard, M. B. (1966). Slums and Community Development: Experiment in self help. New York, Free Press.

3. George, C. K. (2002). Basic Principles and methods of urban and regional planning. Lagos, Libro-Gem Books.

4. Hick, U. K. (1974). The large city: a world problem. London, Macmillan.

5. Jay, M. (2001). Cities at risk. Habitat Debate, 7(34), 1-4.

6. Kiran, M. (2010). Bringing hope to the slums. Footsteps, 83(1),14-15.

7. Wright, R. T., \& Boorse, D. F. (2015). Environmental Science: towards sustainable future. India, Pearson Education Services Pvt. Ltd.

8. Adewale, O. Y. (2019). Analysis of slum formation in core areas of Ilesha, Nigeria. Ghana Journal of Geography, 11(1):20-32.

9. Peters, D., Michael, B., Denis, S., \& James, S. (2008). An Introduction to human geography. England, Pearson Education Limited.

10. Julie, P., \& Diana, T. (2004). Who is the poorest of them all? Development, 25(1), 36-37.

11. Ibimilua, A. F., \& Ibimilua, F. O. (2011). Aspects and topical issues in human geography. Akure, B. J. Production.

12. Areola, O., Mamman, M., Onweluzo, F. A., \& Omotoso, O. (2008). Geography for WASSCE \& SSCE. Ibadan, University Press Plc.

13. Coleman, J. W. (1984). Social Problems. New York, Harper and Row.

14. Hardoy, J., \& Statterthwaite, D. (1989). Squatter Citizen. London, Earthsan Publication.

15. Wilson, W. J. (1987). The truly disadvantaged: the inner city, the underclass, and public policy. Chicago, University Press.
16. Charles, W. (1979). Elements of human geography. London, George Allen \& Unwin Ltd.

17. Hu, M., Yuan, J., Zhou, Z., \& Fucal, L. (2017). Relationships between urbanization, economic growth, industrial structure and nitrogen emission in the Jishui river basin based on a VAR model. Saudi Journal of Humanities and Social Sciences, 2(2), 144-151.

18. Strauss, A. (1961). Images of America city. New York, Free Press.

19. United Nations (UN). (2001). The State of the world's cities. Istambul, Habitat Publication Unit.

20. Bankole, B. O. (2009). Nigerian urbanization and urban development. In A. L. Adesina, O. O. Olufayo \& T. Adefolaju (eds.). Perspectives on urbanization in Nigeria. Lagos Bolabay. Chapter, 13:219-230.

21. Faludi, A. (1973). Planning theory. Oxford, Pergamon Press.

22. Gurr, T. (1970). Why men rebel. New Jersey, University Press

23. Kirk, G. (1980). Urban planning in a capitalist society. London, Groom Helm.

24. Sanni, L. K., Adewoyin, Y., Bako, A. I., \& Akande, O. S. (2018). Urban crime prevention and adaptation measures in Ilorin, Nigeria. Tanzania Journal of Development Studies, 16(2),38-48.

25. Habitat. (1999). The Habitat agenda. Nairobi, Kenya, Habitat.

26. Agboola, E. B. (2009). Dimensions of criminal behaviours in cities. In A. L. Adesina, O. O. Olufayo, \& T. Adefolaju (eds.). Perspectives on urbanization in Nigeria. Lagos, Bolabay. Chapter 6:81-87.

27. Frieden, B. J. (1967). Housing and national urban goals: old policies and new realities. Howard, University Press.

28. Ambika, R. (2006). Working towards urban renewal. Footsteps, 67(1),1-3.

29. Siyanbade, D. O. (2007). Ecological considerations in planning and managing the environment. Lagos, Olive Tree Publishing Ventures.

30. Saunier, R. E. (1999). 'Sustainable development, global sustainability' In D. E. Alexander, \& R. V. Fairbridge (eds.). Encyclopedia of environmental science. Dordrecht: Kluwer Academic Publishers, 587-592.

31. Peter, D., Michael, B., Denis, S., \& James, S. (2008). An introduction to human geography. England, Pearson Education Limited.

32. Sousan, J. G. (1992). Sustainable development. In A. M. Mannion \& S. R. Bowlby (eds.). Environmental issues in the 1990s. Chiester, John Wiley, 21-35.

33. Mohammed, A. I., \& Doaa, M. M. (2016). Smart cities and sustainability: a set of vertical solutions for managing resources. International Journal of Environment and Sustainability, 5(3):1-15. 